\title{
A CAMPANHA PRESIDENCIAL DE ARMANDO DE SALLES E O GOLPE DE 37 NO BRASIL - UM ESTUDO DE CASO DE TRANSIÇÃO PARA O AUTORITARISMO*
}

\author{
Eduardo R. Gomes**
}

\section{INTRODUÇÃO - O GOLPE DE 37 E A QUESTÃO EM PAUTA}

Dentre as várias questøes que envolvem o Golpe de 1937 nao se observa, nas análises correntes, uma maior consideração do significado político das várias alternativas nos setores dominantes à crise pela qual passava o Brasil. Paradoxalmente, a diversidade oligárquica, tão enfatizada nas interpretaçбеs do movimento revolucionário de 1930 , seus antecedentes e desdobramentos, aqui se esvai subitamente.

Com maior ou menor complexidade analítica, o golpe é usualmente derivado de uma insuportável agudização de uma crise política entre "esquerda" e "direita", situação e oposição, de uma crise| econômica ou ainda, mais genericamente, de um grave impasse que só seria superável e superado pela redução autoritária do alto nível de conflito. Nesse sentido, grande parte da reflexão acerca do golpe e do Estado Novo recai sobre a situação de drástica crise que o antecede ou sobre o perfil, a formaçao, desenvolvimento e efeitos da proposta autoritária, que entđo se impōe. ${ }^{1}$ Dessa forma, o peso político de cada grupo dentro das elites, sua influência no conjunto dos setores em luta acaba nao ganhando muito valor explicativo em termos da eclosão do Golpe de 37, a ño ser com o apoio ou oposição à proposta golpista associada a Vargas.

Assim, buscando recuperar melhor a configuraçđo das diversas forças na cena política e, além disso, considerando a reconhecidamente particular inserção de São Paulo na política nacional, voltamo-nos, neste trabalho, para a análise da candidatura de Armando de Salles Oliveira à sucessão de Vargas em 1938 e sua frustração com o golpe. A despeito da importância do estado de São Paulo, esta alternativa sucessória paulista, que então se sobressai, tem sido vista de maneira muito residual nas reflexøes sobre essa temática, lacuna que procuraremos aqui parcialmente cobrir. ${ }^{2}$ 
Nesse sentido, estaremos assinalando, que a candidatura Salles envolveu uma importante - ainda que pouco harmônica - coalizao de forças regionais sobre cuja base sua concretíssima proposta de disputa eleitoral da presidência ameaçou todos que vislumbravam uma soluçao da questao sucessória através das tradicionais negociaçðes intra-elites. E estes, sabidamente, ño eram poucos e nem estavam consensualmente afinados em torno de uma saída golpista.

As possibilidades - e os riscos para seus oponentes - deste candidato vinham sendo há muito formuladas no seu discurso, que não só sustentava a necessidade e as boas perspectivas da real implementação de um modelo democrático-liberal no Brasil - mesmo considerando os "extremismos" -, como também dava conta destes e de outros problemas contemporâneos do mundo e do Brasil. Nesse sentido, suas propostas, que deixam raízes no início de sua função como governador de São Paulo, sđ̃o particularmente singulares e atualizadas, pois que incluem, dentro da afirmação da via democrático-liberal para o Brasil, novas questðes entao como intervenção do Estado na economia, legislaçđo social, etc.

Dessa forma, o Golpe de 37 ño foi tão-somente um golpe contra adversários intra-pares do situacionismo e nem foi também apenas uma intervenção controladora do alto nível de polarização do conflito social ou das dificuldades na vida econômica, inclusive porque, tais problemas já estavam sob controle antes do golpe. Somente de forma simplificada é que ele pode ser assim entendido. Porém, se considerarmos esta intervenção como momento desencadeador da construção de uma nova ordem social democrática nđo-liberal, hierárquica, corporativa, o Golpe de 37 deve ser compreendido também como uma oposição radical às propostas alternativas entao existentes, em particular, aquela que se configurava e se sobressaía com Armando de Salles, propugnando pela via democrático-liberal para a sociedade brasileira até às vésperas da intervençđo, com significativo apoio - entre outros - de setores das elites mineiras e gaúchas.

Quanto a isso, vale a pena lembrar que o golpe estava inicialmente programado para 15 de novembro, mas é antecipado para o dia 10 daquele mesmo mês, tendo exatamente em vista o pronunciamento feito por Salles aos "chefes militares" do país, no dia 8, no qual aquele candidato relata os graves obstáculos então existentes para a realização das eleições de janeiro e apela para a garantia das forças armadas: "Ao Exército e à Marinha cumprirá montar guarda às urnas e velar por que o País obtenha nelas um governo de autoridade - de irrecusável autoridade moral, ao qual darão depois o seu firme apoio, não só para a luta contra o comunismo, como para a obra de organizaçđo do Brasil" 3 
Em suma, mais que uma autoritária intervenção controladora do acirramento de um conflito político polarizado, em termos de "esquerda" e "direita", situação versus oposiçao, ou de problemas na economia, o golpe representou uma radical oposição às regras sob as quais se fazia o jogo político entao, principalmente nos seus aspectos liberais e pluralistas, elementos essenciais da candidatura Salles, como veremos. E será contra essa proposta de organizaçao da vida política brasileira que se constrói toda uma retórica no novo estado que se inaugura.

Assim, distintamente das formulaçбes de Salles, o legado políticoideológico do Estado Novo formado desde antes do golpe compreenderia, como bem sintetizou Ångela Castro Gomes, a concepção "de que o desenvolvimento econômico e social do país ño é compatível com a experiência da liberdade e da igualdade liberais; a idéia de um novo tipo de cidadania que ño se fazia por representaçđo eleitoral e sim por pertencimento profissional; a idéia de uma sociedade hierarquizada e integrada pelo Estado/nação; a idéia de um líder político que simbolizava a 'pessoa coletiva' que é o povo desta nação; enfim, a idéia de um Estado Autoritário que se quer democrático, como a expressao 'natural' das necessidades do país". 4

Apresentada a análise que se segue, cabe situar nossos pontos de partida.

Examinando, portanto, o significado da candidatura Salles frente ao Golpe de 37, este trabalho constitui uma investigaçao de um aspecto específico que é pouco considerado nas reflexøes sobre aquela conjuntura.

Como indicamos, esta intervenção golpista foi entendida em grande parte como uma resultante inevitável da crescente força da facção autoritária, liderada por Vargas, frente a um processo de problemática polarizaçao dos conflitos sociais.

Nesse sentido, Skidmore por exemplo, parece estar convencido de que o "O sistema político aberto, com o seu instável equilíbrio de forças, tinha sido desgastado pelas violências de esquerda e de direita. O Golpe de 1937, determinou finalmente o caminho histórico do Brasil, numa conjuntura crítica". 5 Não se pode desconsiderar, todavia, que este autor também reconhece que a política brasileira dos anos 30 tinha sido caracterizada por uma série de precários acordos entre "constitucionalistas liberais" e "nacionalistas autocríticos", ainda que o primeiro grupo ño ganhe maior valor explicativo na análise do golpe de 37 .

Mesmo em um dos mais detidos - e valiosos - estudos da situação próxima ao Golpe, que é o de Robert $\mathrm{M}$. Levine, rápida consideraçđo se faz quanto as disputas entre as elites, a despeito deste analista mencionar o fato como relevante. Depois de registrar as dificuldades de Vargas em conseguir um razoável consenso entre os setores dominantes, no período cons- 
titucional pós-34, Levine desenvolve toda a sua análise levando basicamente em conta o movimento integralista e a Aliança Nacional Libertadora, frente à ascendência da vertente autoritária. ${ }^{6}$

Nessas interpretaçoes, contudo, raramente é lembrado que a polarização e a intensidade dos conflitos políticos vinham sendo razoavelmente controladas ao longo do ano de 1937.

Muito menos se confirmam as formulações que colocam numa situaçđo de crise econômica as causas do golpe como é o caso do trabalho pioneiro de Lourdes Sola sobre esse tópico. ${ }^{7}$

Nessa análise, a autora sustenta que: "dois grandes conjuntos econômicos, por razôes e através de canais diferentes, convergiam na mesma direção política, apontando para o fortalecimento do Estado: a situação depressiva da cafeicultura e os efeitos desastrosos que provocava sobre a balança de pagamentos, com a queda de nossas exportaçбes, de um lado: de outro, as perspectivas positivas no setor industrial que, por isso mesmo, revelavam as insuficiências de seu desenvolvimento". Ainda segundo Lourdes Sola, também contribuiu para o desfecho de golpistas a "fraqueza das novas oligarquias que contavam com a manutenção do sistema representativo para reforçar seu poder". 8

Pouco mais é dito sobre o último fato e o Estado Novo é, pois, caracterizado basicamente através da implementaçao de várias políticas sociais, econômicas, administrativas estruturadas como respóstas aos já referidos problemas das classes dominantes.

Igualmente significativo, todavia, é o fato de que tanto na área da política industrial como na área da política agrícola poucas modificaçбes se farão notar na atuação do Estado antes e depois de 1937, como a própria autora sugere para ambos os casos. ${ }^{9}$

Além disso, dificilmente se confirmam os problemas de suprimento de bens de capital para a indústria brasileira antes de 1937. Se estes ocorreram, dados mais pormenorizados sugerem que tais deficiências se concretizam depois do ano do golpe. ${ }^{10}$

Trata-se aqui de ir mais além. Sem entrar na discussão dos pressupostos teóricos das abordagens anteriores, podemos ver que as crises buscadas como explicação para o golpe - visto como uma reação contrária a elas dificilmente se configuram como tal.

Cabe, portanto, de entender contra o que se volta o golpe e qual o sentido da autoritária construção de uma nova ordem política marcadamente democrática ño-liberal, que sucede àquela intervenção. Nesse sentido, as explicaçбes devem ser buscadas em outra direçđo, a nosso ver, no impasse entre a existência de uma proposição de uma via democrático-liberal para a organização política e o desenvolvimento do paŕs - consubstanciada na 
candidatura de José Américo e do próprio poder legislativo - e a oposiçao a esta alternativa, presente em setor das elites militares e civis. ${ }^{11}$

Justificando as razoes do golpe para Oswaldo Aranha, em sua correspondência particular, o próprio Vargas inclui o problemático encaminhamento da sua sucessão. Depois de assinalar, para Aranha, a existência de um grande desinteresse por parte da populaçđo na questão sucessória, Getúlio diria, textualmente, a seu embaixador em Washington: "O problema presidencial tornou-se insolúvel, ainda mesmo pela escolha de um terceiro. Nenhum dos candidatos quis abrir mao de seu nome, e a intransigência de alguns elementos políticos nđo permitia outra composiçđo". ${ }^{12}$ A seguir, o chefe do novo estado ño deixaria de acrescentar que as dificuldades foram agravadas pelo "recrudescimento da campanha comunista à sombra da agitaçao política". Estas eram as peças do jogo e as últimas já estavam há muito dominadas razoavelmente. Tratava-se de controlar as outras.

Sem desconhecer a importância de uma reflexao mais global sobre nossas posiçбes - que, sem dúvida, transcendem ao tema em foco - ou mesmo sem desconsiderar a relevância de uma análise de outros tópicos particulares, que são, inclusive, objeto de estudo de outros trabalhos desta pesquisa, nossa atenção estará centrada no exame da candidatura de Armando de Salles, sua formaçao, desenvolvimento e frustraçao com o golpe.

Dentro desta orientaçao, há uma exceção a todos esses estudos sobre o Golpe de 37 e o Estado Novo, que nao se pode desconsiderar, que é o trabalho de Plinio de Abreu Ramos sobre o papel de Sao Paulo frente a esta redefinição autoritária do sistema político. ${ }^{13}$

Contudo, nessa rara e valiosa análise desta conjuntura, basicamente, o autor situa, nas boas relações do grupo de Armando de Salles com a "situaçăo" nacional e os "extremismos", as razízes da falência de suas propostas, como pode-se observar nestas conclusøes: "A conivência de Armando com os atos de força que precedem ao golpe, a expectativa oportunista em que se colocou diante da viabilidade dos votos integralistas e o silêncio em que se manteve diante dos festivais mussolínicos que afrontavam tradicional vocaçao liberal dos paulistas, impediu que ele assumisse, perante a História, a verdadeira postura de um líder democrático, para a qual nao lhe faltavam atributos de inteligência e de liderança."14 Nessa perspectiva, que aponta com propriedade a dissintonia entre o discurso e atuação de Salles, o conteúdo específico de sua plataforma frente às demais propostas, seu efetivo afastamento de Vargas desde o final de 1936, o apoio que articula junto a outros estados ño adquirem maior significado na interpretaçđo do autor.

Nossa análise, portanto, examinará a formação e desenvolvimento da candidatura de Armando de Salles até o desfecho golpista de 1937, procurando situá-la como uma das principais forças alternativas à corrente autori- 
tária que se consolidava, tendo em vista suas alianças e sua plataforma. Disto trataremos no próximo tópico, ao qual se segue um terceiro e último com uma recuperaçđo ampliada de nossas conclusões, por ora indicadas.

O trabalho teve por base um extenso levantamento de jornais da época nos anos de 1936 e 1937, como O Estado de São Paulo, Correio da Manha e Diário de Noticias, entre outros, livros de memórias, arquivos privados do CPDOC, além da bibliografia secundária pertinente ao tema.

\section{A CANDIDATURA ARMANDO DE SALLES - LANÇAMENTO, ANTECEDENTES E O DESENROLAR ATÉ O GOLPE}

\subsection{O lançamento em 1937}

Armando de Salles Oliveira é oficialmente lançado candidato à sucessao presidencial de Vargas, Pelo Partido Constitucionalista de São Paulo, em 15 de maio de 1937 , um sábado. ${ }^{15}$

Apesar de ser esta a data da definição oficial da candidatura, seu nome já se caracterizara publicamente como um dos concorrentes ao cargo máximo na naçao desde antes de sua renúncia ao governo de São Paulo em 29 de dezembro de 1936. Nesta ocasiao, ao transmitir seu cargo ao presidente da assembléia legislativa paulistana, deputado Henrique Bayma, a menção de Armando de Salles a seus objetivos eleitorais é, entretanto, algo vaga e discreta. Discursando entao, ele diz que sua renúncia visa apenas bem servir a seu estado e ao Brasil, num momento cuja gravidade exige que "todos os homens públicos assumam suas responsabilidades e se disponham ao sacrifício."

A seguir, conclui o orador: "O imperativo do dever patriótico, neste ato, é uma pura e bela expressáo de dever patriótico. A atitude do nosso partido vale como uma afirmaçao de fé nos destinos da democracia brasileira. O que nosso partido quer é simplesmente isto: que o Brasil continue."16

Todavia, a moção de seu partido apelando para sua desincompatibilizaçao com o cargo que ocupava, é suficientemente clara no que diz respeito às intençбes de tonı́á-lo um candidato à sucessão de Vargas e também em relaçđo às motivações programáticas desta candidatura .

Assim, considerando a aproximação da primeira eleição direta para Presidente da República com a nova Constituição de 1934, os membros do Partido Constitucionalista, signatários do pedido de seu afastamento do cargo, referem-se a Salles como o melhor "intérprete" do pensamento de São Paulo, neste aspecto: "S๔o Paulo nao pode fugir as responsabilidades que the 
cabem, como participante na escolha de quem possa reunir as preferências das várias correntes democráticas do país para a magistratura suprema da República, em sadia coordenaçao, que desfaça prevençбes e encaminhe o problema com cuidado, não de impor o nome, seño de contribuir para que se eleja o brasileiro que garanta a vigência do regime federativo, em que repousa o engrandecimento do Brasil."17

O desligamento de Armando de Salles do governo paulista, atendendo a esta solicitaçao, significou, de um lado, a primeira e inquestionável definição da existência de uma candidatura à sucessão presidencial, em torno do que, há muito se especulava igualmente muito. Apesar de já ter havido anteriormente manifestaçסes de outros prováveis concorrentes, a renúncia de Salles definiu uma candidatura, na medida em que ele nao se curvou aos esforços entao em curso para que fosse escolhido um candidato único, nem à solicitaçao pessoal de Vargas para que nao se candidatasse, pois que só reuniria oposiçøes em torno de seu nome. ${ }^{18}$ De outra parte, este episódio já situava alguns aspectos das propostas de Armando de Salles, como o federalismo e a democracia, enquanto bases e "anseios", da nação brasileira, elementos que serao a tônica de sua campanha. Entretanto, ño se pode desconsiderar o fato de que haveria alguma voz dissonante dentro do partido Constitucionalista até quase às vésperas do lançamento oficial de Armando de Salles, como foi o caso do pronunciamento do Deputado Moraes Barros, membro da Comissao Executiva do partido, informando, no dia 7 de abril de 1937, que aquela candidatura nao estava resolvida, encontrando-se o assunto ainda em debate entre os constitucionalistas. ${ }^{19}$

Porém, mais que tudo isso, a definiçao desta candidatura fortaleceu decisivamente a possibilidade de que se fizesse a sucessão de Vargas através de eleiçбes, através da livre competição eleitoral, em um momento no qual os mecanismos institucionais de convivência política estavam pouco e mal consolidados, como veremos. Resumindo, diríamos que, com o lançamento deste candidato, a sorte de Vargas - e das forças da Revolução de 30 que predominavam - estava também lançada.

Situa-se aí, portanto, o ponto de partida do segundo tópico deste artigo. A seguir, estaremos examinando os antecedentes da formaçáo desta candidatura e seu desenrolar até o Golpe de 37 , tendo por referência as forças articuladas a Armando de Salles e as propostas por ele formuladas.

Nesse processo, poderemos observar que a alternativa representada por Salles sofrerá uma significativa mudança no seu impacto junto ao poder central e junto a outras esferas políticas do país, exatamente a partir da sua definiçao enquanto um candidato à sucessão presidencial de Vargas, no final de dezembro de 1936. No correr de 1937 Salles passará para a oposição a Vargas e, com esta difícil posição, buscará alianças com diversas forças re- 
gionais.

Não é demais registrar que, quanto a esta renúncia de Salles, o Ministro da Justiça daquele período, e ligado ao candidato Vicente Rao, sustentou recentemente o caráter de protesto antecipado deste gesto pois, para ele, Armando de Salles lançou-se candidato exatamente para tentar evitar o golpe, pois já estava prevenido da possibilidade de uma ditadura no país. ${ }^{20}$.

\subsection{Os antecedentes desde 1933}

Especulava-se praticamente sobre tudo e todos no que diz respeito a sucessão de Vargas. Sem tomar esta afirmação ao pé da letra em termos absolutos, é dessa forma que parecia se definir boa parte do clima político desde o início do período constitucional. ${ }^{21}$ Entre os principais nomes entao considerados para a sucess $َ$ o de Vargas desde sua posse em 1934, contam-se os de Flores da Cunha, Oswaldo Aranha, Antonio Carlos, Medeiros Neto, José Carlos de Macedo Soares e também Armando de Salles e José Américo.

A situaçao de incerteza sobre a conduçao da sucessao presidencial, entretanto, perdura até às vésperas do golpe. Assim, em agosto de 1937, quando a intervençao federal no Rio Grande do Sul caminha a passos largos, circula a informação de que os armandistas estariam esforçando-se por encontrar um tertius que substituísse a candidatura de seu líder e a de José Américo. Mais uma vez, estas negociaçбes nao são bem sucedidas, inclusive pela oposiça dos partidários deste último candidato. ${ }^{22}$

$\mathrm{O}$ intenso clima de especulaçбes sugere muito a existência de um altíssimo grau de incerteza quanto à sucessao de Vargas, ainda que legalmente prevista e mesmo depois da confirmação da sua inelegibilidade pela Justiça Eleitoral no começo de $1937 .^{23}$

No caso de Salles, as origens das especulaçoes acerca do seu futuro político na chefia máxima da nação brasileira podem ser situadas no episódio de sua nomeaçđo, por Vargas, para Interventor em Sao Paulo em agosto de' 1933. Assim, a partir daí, Armando de Salles começa a tornar-se um nome de expressão e circulação nacional, além de, obviamente, ganhar crescente importância no próprio estado que governava.

Neste particular, obviamente não desligado do primeiro, há que se notar, em princípio, que Armando de Salles é o único nome comum nas várias listas que são apresentadas a Vargas para escolher o novo interventor paulista em substituição a Daltro Filho, que assumira interinamente tal cargo no lugar de Waldomiro Lima. ${ }^{24}$

Seis meses depois, em fevereiro de 1934 , o novo chefe do estado de São Paulo, junto a sua agremiaçao partidária, de origem, o Partido Democrá- 
tico, decide fundar uma nova organizaçao, que veio a ser denominado, talvez nao casualmente, Partido Constitucionalista.

Plínio de Abreu Ramos vê na fundação deste partido o objetivo de "mostrar que Sao Paulo necessitava de uma força política que fundisse o programa liberal de $30 \mathrm{com}$ as reivindicaçбes constitucionalistas de 32 , 'uma síntese das aspiraçōes que as duas revoluções defenderam", como foi afirmado por seu organizador. ${ }^{25}$

Todavia, além destas possíveis implicações, a formação do novo partido representou uma grande e renovadora aglutinação da classe política paulista, na medida em que a última organização mais global desta elite, a Chapa Única Paulista, contou com um baixo nível de consenso entre os antigos partidos de Sao Paulo, o Partido Democrático e o Partido Republicano Paulistas, este, inclusive, com séria cisđo interna. Nesse sentido, assinalou-se em uma investigação da presença das forças partidárias de São Paulo na Assembléia Nacional Constituinte de 1934 como foi grande a falta de consenso entre elas: "Em relaçao aos dois partidos paulistas, uma questão salta à vista. Enquanto o PRP conseguiu aprovar seis nomes, de sua lista de dez, sendo que quatro por indicaçao exclusiva do partido, o P.D. conseguia aprovar quatro nomes, dentre os quais apenas um com sua total responsabilidade". ${ }^{26}$ Neste trabalho, os autores lembram ainda que estes partidos nao apresentaram nenhuma indicaçao conjunta e que foram a Federaçao dos Voluntários e a Associação Comercial de São Paulo as duas "organizaçбes uma eminentemente política mas sem caráter partidário, e a outra, uma associação de classe - que conseguiram maior participação na lista de candidatos". 27

A expressividade que ganha este novo partido pode ser também observada através da adesao da grande maioria, que a agremiaçao ganha, dos membros da CUP, entao empenhada nos trabalhos constituintes, tarefa da qual ela vai se desincumbir brilhantemente. ${ }^{28}$

Os testes eleitorais de 1934,1935 e 1936

Contudo, outros testes da importância estadual e nacional de Armando Salles e do Partido Constitucionalista adviriam das eleiçoes federais, estaduais e municipais previstas pela constituição de $1934{ }^{29}$

Neste aspecto, Salles é relativamente bem sucedido, tendo crescido $35 \%$ no número absoluto de votos entre as eleições estaduais e municipais, sendo praticamente nulo o avanço no PRP no ano e meio de intervalo entre um e outro pleito. ${ }^{30}$ Cabe registrar, todavia, que esta agremiaçáo partidária denunciou, inúmeras vezes, a prática de fraudes nestas eleiçoes. As vitórias do PC devem ser consideradas, portanto, em relaçao a relativamente intensas 
disputas entre esses partidos, sem se deixar de lado o fato de que mecanismos além do "voto livre e secreto" foram usados pelos constitucionalistas. $^{31}$

Talvez menos que em termos apenas numéricos, Armando de Salles e seu partido ascendem com amplo sucesso no seu estado e na esfera federal, dimensб̃es que devem ser consideradas conjuntamente.

Este nome de consenso nas propostas para nomeação do interventor no e do estado e entre os paulistas e o governo federal, para a "pacificação" de São Paulo, capitaneou a criação de uma nova agremiação partidária que ganharia grande expressao local e nacional. Assim, o Partido Constitucionalista foi, ao mesmo tempo, uma iniciativa de reorganização das forças partidárias do estado - sem dúvida enfraquecidas, como se pode ver na formaçao da CUP - e ligou-me ambiguamente às diligências de Vargas de criar partidos situacionistas nos estados.

Tal aglutinaçao de forças estaduais, facilitada pela uniåo de uma cisđo do PRP ao PC, teria ainda grande importância na vida política nacional, ao ganhar a adesđo da maioria dos membros da Chapa Única Paulista na Constituinte. Nessa atuação, a CUP, coesa, mantém-se dentro dos limites dos debates constitucionais o que reforçaria imensamente a força de suas propostas. Além disso, sem deixar de representar Sđo Paulo, desenvolve também um trabalho de aproximação com bancadas ligadas ao Governo Provisório. $\mathrm{E}$, last but not least, a CUP é igualmente eficaz no que concerne seu projeto político mais amplo, que envolve uma redefinição dos valores liberais: "Se, através dos debates parlamentares os paulistas reafirmam, entre seus princípios básicos, a defesa do liberalismo e do federalismo, eles agora também passam a admitir a necessidade da intervençao estatal, da maior eficácia da política econômica. Essa evoluçao é por eles mesmos justificada em função das transformaçōes históricas por que passa a sociedade." ${ }^{32}$

\section{O Partido Constitucionalista e Vargas até 1936}

Desde a fundação do Partido Constitucionalista até o início de 1937, serđo observadas também relaçбes de muitas afinidades entre Sđo Paulo e o poder central, que resultaram em inegáveis benefícios para Vargas e para os paulistas, ou pelo menos, para o grupo armandista nesta unidade da federação.

Assim, quando da reformulaçao ministerial em julho de 1934, o Partido Constitucionalista seria agraciado com pastas ministeriais e outros cargos na alta administração federal. ${ }^{33}$ A presença destes paulistas na alta administração federal seria vista, mais tarde no congresso de 1936 do Partido Constitucionalista, como a própria "presença" de São Paulo no governo fe- 


\section{deral. ${ }^{34}$}

Por outro lado, Vargas contaria com o apoio permanente do Partido Constitucionalista no Poder Legislativo, além da colaboração mais direta de Vicente Rao, no Ministério da Justiça, para estabelecimento de todos os mecanismos legais de limitaçao da vida democrática no país: a Lei de Segurança Nacional, de 4 de abril de 1935, a instalaçao da Comissão de Repressão ao Comunismo em 10 de janeiro de 1936. Além disso, este político de Sao Paulo colaboraria decisivamente para a criaf̧o do instituto do "Estado de Guerra", assim como do Tribunal de Segurança Nacional, outros dos principais instrumentos "excepcionais" de repressão naquele momento. ${ }^{35}$

Além das eleiçб̃es para governador e senadores, e posse desses representantes, além do início da colaboração mais íntima entre Sao Paulo e o governo federal no estabelecimento de restriçб̄es à Constituiçđo de 34 , o ano de 1935 seria marcado politicamente pelo episódio da Intentona Comunista, nos últimos dias de novembro, movimento ao qual os políticos paulistas, mais uma vez, reagiram em estreita afinidade com o poder central.

A temática da "ameaça comunista" como o principal inimigo à viabilização da democracia no país já representava e permaneceria ainda por muito tempo e com grande peso no discurso oficial, além de, obviamente, ser uma das motivaçбes para o estabelecimento de medidas concretas de repressao cada vez mais coercitivas.

Assim, no seu discurso pela passagem de ano, de 1935 para 1936, Getúlio Vargas ressalta: "O comunismo, encarado como força desintegradora e agente provocador de sérias perturbaçбes, constitui, no Brasil, pela sua profunda e extensa infiltraçao já comprovado, mas desconhecida ainda do público perigo ainda maior que se possa supor."36

A acolhida paulista a esta linha nao é desprezível, para nđo dizer, valiosa. Hélio Silva informa que, nesse momento, Valdemar Falcão propø̃e, no Senado, um projeto de ensino visando combater ideologias comunistas e, além disso, o Ministro Vicente Rao, com os mesmos objetivos anti-comunistas, ressalta a necessidade de uma maior organizaçđo capaz de fazer a vigilância, e a repressฐ̃o contra esta infiltraçđo tanto nas forças armadas como nos meios civis, obviamente atendida. ${ }^{37}$

Assim, não é de se estranhar que o aniversário da capital do estado no início de 1936, tenha sido comemorado em ambiente de grande confraternizaçao entre o governo paulista, o poder central e as forças armadas.

$\mathrm{Na}$ comemoração daquela data, o governador Armando de Salles salientou o regionalismo do Brasil e sua força, que nao desagrega o país, a partir do que criticou duramente a Intentona Comunista: "O que se sente é que todos nós, brasileiros, guardamos na alma um único modo de ser, uma mesma religiao, um mesmo instinto de pátria. Pois, foi tudo isso que quise- 
ram romper e extinguir há dois meses. Uma horda brutal, conduzida por agıtados e agitadores sem pátria, tentou apoderar-se do Brasil democrático. do Brasil cristão. ${ }^{38}$

Discursando naquela mesma ocasiao, o General Pantaleao da Silva Pessoa, Chefe do Estado Maior do Exército, além de congratular-se com o evento disse que esta torça armada nao desestima o federalismo e a democracia, o que indica a busca e as perspectivas de confraternizaçao entre os militares e Sao Paulo. Entretanto, isso nao é tudo

Getúlio Vargas, por sua vez, cumprimentaria Armando de Salles por aquela comemoraçao com o seguinte telegrama que, talvez exprima, acima de qualquer suspeita, as boas relaçoes que existiam entre eles: "Tenho a satisfaçao de enviar-lhe efusivas saudaçð̄es por motivo da comemoração do aniversário de São Paulo. Associando e através da representaçao das forças do Exército e da Armada às festividades comemorativas dessa magna data, quis significar o alto apreço do governo do Brasil ao grande Estado, que é, no seio da pátria, um padrão de prosperidade e de esforço construtor e fecundo."39

O desenrolar do ano de 1936 seria, pois, caracterizado por uma série de puniçðes diversas nos meios civis e militares por suspeitas de envolvimento - ou envolvimento de fato - com a intentona e o movimento comunista em geral. Os membros da Aliança Nacional Libertadora e da Ação Integralista Brasileira estavam - certamente ño com a mesma precisão - também sob a mira das forças de repressão, esta última, pelas supostas ligaçoes com o Nazismo alemão. ${ }^{40}$

$\mathrm{O}$ apoio a estas medidas era bastante generalizado nos meios políticos transcendendo, portanto, ao de São Paulo e mesmo a este grupo. No princrpio de janeiro, ao receber jornalistas cariocas e o presidente da Associaçao Brasileira de Imprensa, Vargas agradeceria o apoio dos jornais do Rio de Janeiro no combate ao comunismo. Além desta e de outras manifestaçōes, o Presidente da República é elogiado pela Câmara do Comércio e Indústria do Brasil pela sua luta contra os "extremismos." 41

As propostas do Partido Constitucionalista e de Salles antes da sua candidatura

Depois de sua fundação em 1934, realiza-se em meados do mês de fevereiro de 1936 o $2^{\circ}$ Congresso do Partido Constitucionalista, quando, por iniciativa de Ernesto Leme, é aprovada uma moção de homenagem aos mi. nistros José Carlos de Macedo Soares e Vicente Rao, considerando que eles representavam nas suas pastas, respectivamente a do Exterior e a da Justiça. a orientaçao política do estado de Sao Paulo. ${ }^{42}$ 
Na notícia do encontro, depois de se considerar que, em regra, a crise econômica nao exige uma mudança "extremista" necessária na política, enfatiza-se mais uma vez, a perspectiva do partido que sustenta a primazia da via democrática para Sao Paulo e a sociedade brasileira: "O ideal seria que, na presente conjuntura, todos os paulistas mostrassem, por atos e palavras, que ño precisam de regimes de força, como, por exemplo, o fascismo, para realizar seus progressos. Se os "fascismos", em países assoberbados por crises financeiras, conseguem impor a ordem absoluta, nao atinamos por que a democracia com melhores recursos morais ño alcança o mesmo objetivo." 43

Era também voz comum neste grupo político a necessidade de se reformar parcialmente a democracia, como assinalou por exemplo, o congressista Otávio Castelo Branco, ao saudar, em nome dos demais membros da reuniao, o novo diretório eleito. Referindo-se às eleiçбes legislativas de 1934, diz: "O povo de Sao Paulo, a 14 de outubro, consagrou o programa do partido, e estamos certos de que, com a direçao que acabamos de dar ao partido, ele continuará a merecer a estimativa do povo de Sao Paulo; o apoio da opinião pública do estado porque o Partido Constitucionalista é um partido que ñ̃o faz a democracia romântica, democracia demagógica, mas faz a democracia que defende a liberdade, restringindo-a estabelecendo-lhes limites para que seja leal." 44

Até 15 de março, o entao governador de São Paulo estaria se dedicando, basicamente, à campanha de seu partido para as eleiçбes municipais do estado naquela data. Já nestes discursos pronunciados por Armando de Salles em 1935 e 1936, configuram-se com muita clareza os princípios de sua plataforma política, idéias que igualmente nortearao sua candidatura a sucessão presidencial no ano seguinte.

Assim, nestes e em outros pronunciamentos e $\mathrm{cm}$ manifestaçбes oficiais do Partido Constitucionalista ao longo de 1936, a ordem liberal-democrática seria defendida como a melhor opção para a sociedade brasileira, por vários motivos, em uma proposta bastante articulada.

Referindo-se à crescente ascendência dos movimentos e propostas políticas totalitárias no mundo, quando da sua posse como governador em 1935, Salles afirma sua crença na excelência da democracia, mesmo diante das oposições que esta sofria: "Tendo a convicção de que a fórmula democrática renascerá da crise atual, quando o mundo se fatigar de certas utopias fascinantes, velhas como ele mesmo, e que, às vezes, reaparecem com ares remoçados, graças a artifícios brilhantes e hábeis." 45

Tratando especificamente do caso brasileiro, diria, em ouiubro de 1936, que o totalitarismo nao é soluçao para o "contágio marxista", podendo, pelo contrário, estimular a vitória desta força em vista da artificial e 
insuportável centralização que seria imposta: "A centralização traz o germe da morte inevitável: atirando o país, mais cedo ou mais tarde, na guerra civil, conduziria à desagregação."46

Por outro lado, Salles sustenta a imperiosa necessidade da liberdade, da diversidade, do pluralismo partidário. Assim, além de rejeitar radicalmente a idéia de democracia como sinônimo de "unanimidade", ele vê nos partidos políticos um dos elementos decisivos para o renascimento e fortalecimento da ordem democrática. E, mais do que apenas formular princípios, nesta e em outras ocasióes, Armando de Salles propбe-se a realizar as condiçб̃es para tal ordem política, no caso em São Paulo, como disse ao assumir a chefia deste estado: "A minha ação será a de tornar fácil o terreno para que os partidos paulistas, longe de renunciar à existência fundindo-se uns com os outros, vivam em constante emulação, disputando-se a primazia na devolução do interesse público."47

Ainda dentro dessa questão unidade/pluralidade, Salles ressalta especificamente o papel nao-desintegrador da diversidade regional do país e a importância do federalismo para traduzir essa realidade brasileira. Este foi um dos pontos tocados por este político ao saudar as forças armadas, em um banquete a elas oferecido por São Paulo, quando do aniversário de sua capital em 25 de janeiro de 1936: "Longe de amortecer a unidade nacional, o regionalismo dá-lhe vida e colorido. A integridade territorial e espiritual ño é incompatível com a existência de um regionalismo persistente e vivaz. Unidade não significa uniformidade. Cada uma das regiøes do país cultiva e resguarda as tradiçres locais, os costumes e as peculiaridades da vida social, mas permanece brasileira, visceralmente brasileira. As múltiplas combinações dessa diversidade é que constituem a grandeza da pátria."48

Considerando tal diversidade do Brasil, aquele político vê no federalismo a melhor maneira de organizar o país, de fazê-lo progredir, postulaçđo que encontra confirmaçao insofismável na história brasileira, segundo ele: "Profundamente arraigadas ao sentimento regional, as províncias brasileiras tentaram várias vezes combater o regime centralizador, que as condenava à estagnaçđo. A queda da monarquia deu-lhes a autonomia política e administrativa a que aspiravam. De asas livres, realizaram em poucos anos um progresso notável."49

Assim, conclui, em termos mais amplos: "O exercício da autonomia e o incontestável erro do regime, vingaram ainda mais profundamente o antigo sentimento das províncias brasileiras e, depois de quarenta anos de experiência republicana, o princípio da federaçđo como condiçđo básica da unidade do país é a mais viva das realidades nacionais." 50

Salles, ao retomar nesta e em outras vezes a defesa do federalismo como a organizaçao mais expressiva da diversidade do país iria aparecer 
e de fato ser combatido como - um inimigo da Revoluçao de 30. Forçoso é reconhecer, entretanto, que este federalismo nao excluía um importante papel para o poder central.

Nesse sentido, como já foi em parte indicado, seu discurso nao se constituía ęm uma "romântica" proposta de uma organizaçao liberal-democrática. Esta era pensada de acordo com o momento, para o qual reconhece-se igualmente a importância de um poder executivo central fortalecido -através do presidencialismo - seja para a defesa contra as "ameaças externas", seja pelas novas funçôes econômicas e sociais que o Estado deve assumir, na sociedade contemporânea: "O regime presidencial é a robusta armadura com que defenderemos as instituiçбes republicanas. Não a trocaremos por outra, por mais brilhante que seja a sua aparência. A lição do que se passa com os povos que querem vencer as suas crises sem apelar para o supremo recurso de uma ditadura de direita, traça-nos o caminho. Poderemos, se quiserem, ajustar melhor a couraça do sistema presidencial ao cargo do Brasil, mas com o objetivo de lhe dar um poder executivo forte, capaz de assegurar a ordem pública, de reparar as finanças e de aniquilar as investidas bolchevistas." 51

Uma outra transformação também importante da vida contemporânea, por ela apontada, é a profunda redefinição das relaçđes entre o capital e o trabalho, envolvendo mudanças na ordem política no sentido de uma maior intervenção reguladora por parte do Estado: "O patrão deixou de considerar como principal funçao do Estado a de assegurar seus privilégios. E sabe que, sem concessøes aos direitos do trabalhador, o poder econômico lhe escapará das máos." 52

$\mathrm{E}$, nesse aspecto, o Brasil nao se distancia do movimento mundial, ainda que, conforme Armando de Salles, nossa legislação social esteja sujeita a reparos, ela é capaz de satisfazer às "classes trabalhadoras" e foi criada sem maiores violências. ${ }^{53}$

Por último cabe ressaltar que esse conjunto de propostas políticas, recuperadas dos discursos de Sălles em 1936, concebem a democracia-liberal, redefinida nos termos anteriores, como uma das condiçбes para o "progresso" alcançado por Sđo Paulo, razao pela qual tal ordem será igualmente colocada como o mecanismo proposto para o desenvolvimento do país, aparecendo, inclusive, a melhor alternativa para solucionar os nao poucos impasses políticos do país, entao. Referindo-se ds perspectivas de seu partido nas eleiçбes municipais de 1936, diria Armando de Salles: "Mais uma vez se verá que os princípios e a estrutura do Estado democrático, quando respeitados, garantem ao povo o governo de representação e de progresso social, que ele conquistou há mais de um século."54 
Defendendo de público estas propostas desde 1935, as quais, muito provavelmente, ño encontravam eco em grande parte dos valores políticos dominantes, Armando de Salles e o Partido Constitucionalista ascendiam politicamente no seu estado e no cenário federal.

Sob essa mesma orientaçao e esses mesmos valores, é fato, Armando de Salles e elementos do seu partido, como Vicente Rao e Waldemar Ferreira, apoiavame/ou colaboravam ativamente com o poder central no estabelecimento de restrições à vigência de uma ordem democrático-liberal no Brasil, como também já indicamos anteriormente. Plausível ou nao, esta era a situaçao: estas eram duas faces da mesmíssima moeda. Entretanto, mais que ressaltar a incongruência entre elas - o que nos levaria, pouco proveitosamente, a refletir sobre qual é a mais verdadeira, a dominante - cabe, antes, pensar sobre sua efetiva convivência.

A colaboração do Partido Constitucionalista no estabelecimento de medidas coercitivas de "exceçā", de um lado, não desafina de coro quase nacional de apoio a esta repressðo, e, por esse prisma, ño é um caso particular.

Contudo, se, por outro lado, destoava do discurso de Salles e de seu partido, não se pode desconsiderar que este político e alguns de seus correligionários explicitamente reconheciam uma certa necessidade de um foríalecimento do executivo, em vista de "ameaças" a este, o que sugere a existência de um espaço para integraçao deste item à orientaçao liberal mais ampla. $^{55}$

No entanto, distintamente de muitas e importantes forças regionais como Minas, Rio Grande do Sul, e do próprio poder central, Armando de Salles e o Partido Constitucionalista desenvolveram um estruturado projeto liberal-democrático de organização política e desenvolvimento-social, que, além disso, deitava raízes na história recente do estado de São Paulo. Nesta proposta, e no apoio que recebem de outras importantes forças regionais, talvez residisse sua singularidade. E sua importância.

\subsection{O desenrolar até o golpe}

A situação de Armando de Salles e do Partido Constitucionalista se modificariam sensivelmente em São Paulo e no cenário federal com a explicitaçao de suas pretensø̄es de concorrer à sucessao presidencial de Vargas na passagem do ano de 1936 para 1937.

Com pequenas ressalvas, pode-se situar neste momento o início da campanha deste candidato, a qual será marcada por uma significativa aglutinaçao de apoio de forças internas e externas a seu estado e pela propaga- 
ção, a nível nacional, de suas propostas anteriores de desenvolvimento do país através de uma via democrático-liberal.

Depois do episódio de sua renúncia ao governo de São Paulo, colocando-se ipso factu como postulante a sucessao de Vargas, Armando de Salles Oliveira seria oficialmente escolhido candidato do Partido Constitucionalista à Presidência da República no Congresso extraordinário daquela agremiação em 15 de maio de 1937. Porém, entre a renúncia ao governo de São Paulo e a definiçao oficial da candidatura pelo partido muita coisa aconteceria.

\section{Repercussбes}

Em primeiro lugar, devem ser observadas as repercussões da renúncia de Armando de Salles, que é, de imediato, aplaudida por Oswaldo Aranha, por este ver nela um bom passo para a consolidaçao da democracia no país, posição que é seguida por "O Globo" e por Assis Chateaubriand no Rio. ${ }^{56}$

Nessa mesma ocasiao José Carlos de Macedo Soares escreveria a Vargas, dizendo que recebera informaçбes de Sao Paulo que lhe configuravam a situaçao política diversamente da cisão que se propalava. O Ministro das $\mathrm{Re}$ laçбes Exteriores assegurou ao Presidente nao ter havido rompimento dos compromissos dos partidos que apóiam o governo e, mais ainda, que permanece inalterada a solidariedade entre o governo paulista e o poder central. $^{57}$

Dentro do estado, o Partido Republicano Paulista procura ganhar força entrando de imediato com ação na justiça eleitoral contra a eleiçao, pela assembléia legislativa, de um outro membro do Partido Constitucionalista, Cardoso de Mello, para substituir Salles no governo de São Paulo, alegando a inconstitucionalidade de tal processo de escolha. A açao é derrotada em todos os níveis, sendo em 7 de abril de 1937 a decisão final do Supremo Tribunal Eleitoral. ${ }^{58}$

Flores também se movimentaria por conta própria e um dos principais apoios buscados pelo governador do Rio Grande do Sul para si e para Salles foi o Partido Republicano Paulista, através da pessoa de Silvio Campos. Depois de várias marchas e contra-marchas, inúmeros contatos, tal apoio mostra-se inviável, não definitivamente é claro, pois num futuro nao muito distante aquele político perrepista lideraria uma cisao de seu partido alinhandose a Armando de Salles e, conseqüentemente, colocando-se também lado a lado com Flores. Tal uniao de forças, todavia, aconteceria demasiadamente tarde para provocar qualquer mudança nas relações de forças. ${ }^{59}$ 
Primeiro movimento no estado

A primeira manifestaçao do candidato seria no banquete promovido em sua homenagem pelas "classes conservadoras" de São Paulo, em 24 de janeiro, alguns dias depois de terem manifestado, em proclamação pública, uma gratidão especial a Armando de Salles.

Esta homenagem foi preparada e realizada sob condições as mais especiais.

O jornal $O$ Estado de São Paulo publicou, desde o dia 12 de janeiro, um manifesto de apreço das "classes conservadoras" pelos trabalhos de Armando de Salles em prol de São Paulo, proclamaçao com a qual também convocavam para um jantar em homenagem ao ex-governador no dia $24 .^{60}$ Pois bem, assinado inicialmente por poucas entidades, entre as quais, FIESP, ACESP, Sindicatos dos Comerciantes de Café de Sao Paulo, Bolsa de Cereais de São Paulo, o manifesto de convocação ganharia dia-a-dia novas adesбes e maior importância no periódico, até que figurassem nas vésperas do evento cerca de 1200 pessoas e entidades homenageadoras. ${ }^{61}$

No banquete, que teve lugar no Teatro Municipal na véspera de uma das mais importantes datas do calendário paulista, que é o aniversário de fundação da capital, Armando de Salles, mais uma vez, nao faz uma mençao direta a seus objetivos eleitorais, mas faz um significativo balanço completo de sua atuaçao como político, com projeçбes para o futuro, é bom dizer.

No discurso então pronunciado, Salles procura mostrar os bons frutos de sua administraçao em todas as esferas da vida paulista. Sem desdenhar problemas que persistem, o orador assinala os resultados positivos da agricultura, indústria, comércio e finanças do estado, em particular a significativa recuperaçao destas atividades em vista das dificuldades econômicas do país e do mundo. ${ }^{62}$

Assim, Salles assinala, por exemplo, os benefícios da diversificaçao da agricultura paulista, principalmente em um momento de retraçao da demanda externa, situaçao da qual ele tem pleno conhecimento: "Com a exportação de produtos novos, de grande influência nos resultados gerais do nosso intercâmbio, como as frutas, o algodao e seus subprodutos, surge a tendência para uma distribuição geográfica igualmente variada. Em lugar de dependermos estreitamente, como antes, de dois ou três mercados, contamos hoje com muitos outros". 63

Assinalando, com muito otimismo, o que talvez possa ser classificado como excelente desempenho de todos os ramos da economia paulista, Armando de Salles procura igualmente salientar - contra opiniøes em contrário - que São Paulo nāo é "reduto de uma plutocracia massiça, orgulhosa e ávida, cujo poder seria uma ameaça para o progresso social da nação" 
Salles vai de encontro a esta concepção com a maior clareza possível, inclusive, negando ser um "membro ativo" e "servidor obediente" desta "terrível plutocracia", como é visto. ${ }^{64}$

Nesse aspecto, o orador vai indicar, brilhantemente, que apesar de tẹr nascido em fins do século passado com o apogeu do liberalismo - "certamente uma época feliz para a civilizaçđo ocidental" - ele mudou, como igualmente se modificaram os princípios liberais, em particular, frente às questôes sociais: "A minha educação e as tendências do meu espírito nunca me levaram, entretanto, a considerar a ilimitada ambição de bens materiais como o fim principal da vida do homem, por menos que seja a sua capacidade de ser útil em objetivos mais elevados. Homem de meu tempo mas, sobretudo, homem de minha terra, nao corando de temer a Deus e acreditando nas virtudes do trabalho e do patriotismo, jamais me perdoaria como idólatra da riqueza". 65

Armando de Salles sustenta ainda que, empiricamente, nao há grande concentração de riqueza em São Paulo, ocorrendo, na verdade, um processo de repartição dos bens e valores. Por esta situação da realidade paulista e por aquelas razðes de ordem filosófica, nao há por que temer, portanto, a chamada "plutocracia paulista", segundo ele. ${ }^{66}$

Depois de passar em revista as realizaçбes de Sđo Paulo e os princípios aos quais este desenvolvimento se subordina, o orador conclui seu discurso apresentando seus - ño apenas seus - possíveis objetivos além das fronteiras do estado: "Nao será certamente imperialista e muito menos criminosa a ambição que nós, paulistas, tivemos de estender a todo o Brasil métodos que já fizeram sua prova e que produziram na sociedade paulista uma evidente elevação da dignidade do homem."

Tentativas de articulação extra-São Paulo

Ainda no mesmo mês de janeiro de 1937, Sao Paulo receberia visita dos governadores da Bahia, Santa Catarina e Minas Gerais, que atenderam ao convite oficial do chefe paulista feito através de Waldemar Ferreira. Além destes, estivera também em Sá Paulo o governador de Pernambuco, Lima Cavalcanti. ${ }^{68}$

Estas visitas a terra paulistana que constaram de banquetes e viagens ao interior do estado, visavam também propriciar encontros para se negociar a candidatufa de Salles com aqueles governadores.

Como bem se sabe, nao se chega a um consenso em torno do nome de Armando de Salles, como era desejo do situacionismo paulista, ao buscar o apoio de Juracy Magalhðes, Lima Cavalcanti, Nereu Ramos e Flores da Cunha. 
Os visitantes de Sao Paulo, na verdade, acabavam de chegar de um rápido "veraneio político" em Poços de Caldas, onde estava Getúlio e onde ficara bem acertada a posição contrária a um entendimento com São Paulo.

Nao só Armando de Salles nđo conseguiu apoio daqueles políticos como estes tinham outros planos, que praticamente impossibilitavam qualquer desenvolvimento de um acordo. "Juracy pretendia reivindicar o posto para a terra que governava, na pessoa de Medeiros Neto. Se nao fosse possível o nome baiano, propunha, ainda, fosse dado ao Norte a Presidência que tocara ao Sul. Era motivação para o bloco do Norte, robustecida com a mística do espírito revolucionário. Surgia o nome de José Américo com o apelo aos militantes de 22, 24 e 30" ${ }^{69}$ Este nome, entretanto, chocava-se com Lima Cavalcanti. E, por outro lado, Flores, sob atritos crescentes com Vargas, procurava aliados para si no choque iminente com o poder central.

Contudo, alguma coisa foi conseguida a partir destes entendimentos entre os governadores. A despeito de muitas versøes apresentadas e contraapresentadas, Flores acaba admitindo a existência de um pacto defensivo entre os estados do Rio Grande do Sul, Bahia e Så Paulo contra a intervenção do Governo Federal acertado nessa época. ${ }^{70}$ Pelo acordo, cada um dos governos comprometia-se a agir em favor dos outros em caso de intervenção federal, como se a intervenção fosse a seu próprio estado.

O lançamento oficial de Salles a 15 de maio de 1937

Pouco tempo depois, as propostas do Partido Constitucionalista e de Armando de Salles seriam melhor explicitadas com o lançamento oficial de sua candidatura e o desenrolar da campanha.

Para tanto, o partido convocou, em 24 de abril, um congresso extraordinário para meados do mês seguinte com a finalidade de definir oficialmente seu candidato.

Já na abertura desta convocação, coloca-se claramente que as eleiçбes de 1938 serão o teste da democracia no Brasil: "A nação aguarda ansiosa o momento de experimentar, nas urnas, a solidez da democracia brasileira. $\mathrm{Na}$ disputa eleitoral que se aproxima, o regime, que as extremas profiam em abolar, precisa manifestar com eloqüência todas as suas virtudes."71

Nesta expectativa e na defesa arraigada da primazia da ordem democrática para a sociedade brasileira, Armando de Salles e o Partido Constitucionalista vêm sua "expressao moral perante o Brasil" fortalecida, na medida em que, agindo com absoluta lisura, fora promovida, dentro do prazo legal, a desincompatibilização de Salles do seu cargo de governador de São Paulo. E, cabe lembrar, nenhum outro chefe estadual fez o mesmo, vale dizer, nao se tornou candidato à sucessão de Vargas. Ou seja, as opçōes para escolha de 
um nome, para disputar a sucessão presidencial, de acordo com os padrøes legais vigentes, nao poderia mais ser feita com os entao governadores estaduais, à exceção de Salles.

A convocaçao justifica seu pedido de reuniao para escolher este nome desde que entende que já "Armando de Salles Oliveira aparece aos olhos da Naçao como o de um dos mais dignos de ocupar a suprema magistratura do país." Segundo o manifesto, a expressiva solidariedade àquela candidatura, oriunda de todos os recantos do país, deixa raízes, basicamente, no fato de o chefe daquele partido ter traduzido "os mais arraigados sentimentos do povo brasileiro, ao reafirmar a sua fé inabalável nos princípios da democracia."72

Assim, além de reafirmarem a confiança nas forças armadas e no Presidente da República e o repúdio aos "extremistas", os signatários da convocaçao relembram, nas palavras de seu líder, as motivações liberais-democráticas para a campanha, como ele mesmo há pouco enunciara: "O Brasil tem o direito de exigir que nao se corrompam princípios em nome dos quais se erguem, em movimentos espontâneos e irreprimíveis. Alcançamos um dos grandes ideais: o voto secreto, protegido e garantido pela justiça. Desmentimos, em três eleiçбes, o pessimismo dos detratores de nosso povo, servindonos, com inteligência, daquele maravilhoso instrumento de defesa dos povos livres. Preparamo-nos agora para a experiência definitiva, em que se consolidará a ordem constitucional no Brasil."73

Ao apresentar o nome de Armando de Salles, durante o congresso, o deputado Waldemar Ferreira assinala que esta candidatura ño é de oposição a Vargas e registra ainda a repercussão desta proposta nos estados do Rio Grande do Sul, Pará e Estado do Rio de Janeiro. Destes estados, comparecem como representantes ao encontro, o deputado Joao Carlos Machado, líder da bancada liberal gaúcha e Monteiro Filho, delegado da Frente Única Paraense. ${ }^{74}$

Em seu discurso, Armando de Salles ressalta sua crença na realização das eleições, a despeito dos alarmantes sinais que entao se vislumbravam no país, e descarta a possibilidade de se chegar a um candidato único, como já se cogitava.

A partir daí e no de sua campanha, Armando de Salles reafirmaria os princípios liberais-democráticos de sua plataforma, a relevância crucial de seu projeto para a sociedade brasileira, ao mesmo tempo que ressaltaria suas divergências com o poder central.

Neste mesmo discurso de 15 de maio de 1937, Salles assinala que a ordem a que também aspiram - ele e seu partıdo - é "a ordem moral, a ordem estável, a ordem que sıgnifica tranquilidade nos espíritos e esquecimento de todos os sofrimentos dos últimos anos". Em seguida, complemen- 
ta: "Para alcançar essa ordem e encerrar o ciclo das revoluçôes, temos apenas que defender com ardor o que elas nos trouxeram de bom" 75

Além disso, afirma que alguns governadores que permaneceram fiéis aos ideais da Revolução de 30 "sofreram rudes golpes", que é o que igualmente lhe esperaria se, por "prudência" permanecesse no governo de Sðo Paulo. Nessas condiçбes, conclui: "Eu ficaria obrigado, neste caso, a uma irrestrita submissao à vontade glacial que preside à nação, sob pena de represálias implacáveis que, pelo que estamos vendo, sđo de natureza inédita em nossa história. A vela, portadora de nossas esperanças patrióticas, teria de ancorar na enseada do Catete ou se perderia...,76

$\mathrm{O}$ distanciamento com o governo federal que vai se definindo não o afasta de seu projeto, pois, nesta mesma ocasiao, reafirma seus princŕpios liberais-democráticos para organizar e desenvolver a nação brasileira: "Nao. os verdadeiros detentores da idéia nacional não são os homens de extrema esquerda, ño os militantes de extrema direita, ño são os partidários de ditadura: somos nós, os que carregamos o estandarte da democracia."77

A campanha eleitoral de alistamento e de recursos financeiros do Partido constitucionalista fora iniciada, contudo, em 10 de abril, recebendo. de imediato, congratulações do Partido Republicano Mineiro. ${ }^{78}$

Até a formação de seu partido nacional, a Uniao Democrática Brasileira, Salles receberia muitos apoios, sendo que os politicamente mais significativos vieram do próprio PRP cindido, do Rio Grande do Sul e de forças ño situacionistas da Bahia, Distrito Federal e Minas Gerais. ${ }^{79}$

Evidentemente que nem só de aplausos vivia este candidato. Em uma de suas raras manifestaçбes públicas neste período, Vargas discursaria no final de abril criticando os "regionalismos" na vida brasileira e afirmar do que estes vão de encontro aos interesses nacionais, numa clara referência a Armando de Salles. Este pronunciamento seria imediatamente revidado por Otávio Mangabeira na Câmara dos Deputados, o qual por sua vez, foi contestado por Pedro Aleixo. ${ }^{80}$

Salles, contudo, sofrera uma verdadeira perda nas suas hostes com a derrota de Antonio Carlos para Pedro Aleixo na eleição para a presidência da Câmara dos Deputados no início de maio. ${ }^{81}$ Ainda que a derrota tenha se dado por uma estreita margem de votos, a candidatura de Pedro Aleixo foi intensamente trabalhada por próceres gaúchos como Jođo Neves, Baptista Luzardo, setores do PRP e Benedito Valadares, certamente, sob os auspicios de Vargas.

Outro importante baque nas forças favoráveis a Salles nesse momento pode ser localizado na transferência da execuçđo do Estado de guerra no Rio Grande do Sul das maos do governador para o comandante da regiao militar daquele estado. ${ }^{82}$ Tal medida foi tomada e mantida sob intensos protestos 
de Flores da Cunha e de deputados na Câmara. Flores, na verdade, tentała reaproximar-se de Vargas no início do mês, porém, talvez nao o suficiente. ${ }^{83}$

$\mathrm{E}$, de fato, a intervenção do poder central aumentara ainda que nao de forma irreversível, como veremos. Nessa altura, tanto o Distrito Federal como Mato Grosso já estava sob intervenção federal. ${ }^{84}$

Cabe lembrar, ainda no que se refere às forças contrárias a Salles, que, neste mesmo período, sob o comando de Benedito Valadares, estava sendo articulada a candidatura concorrente de José Américo de Almeida, que viria a ser lançada poucos dias depois - 25 de maio - em uma convenção nacional no Rio de Janeiro com representantes de todos os estados do país. Uma semana antes inclusive, Benedito Valladares já declarava como certa a possibilidade da escolha de um candidato no dia 25 de maio, tendo em vista as negociaçбes entao desenvolvidas em Minas com representantes do Amazonas, Rio Grande do Norte, Alagoas, Pernambuco, Bahia e Santa Catarina. ${ }^{85}$

\section{A nacionalização da campanha}

O mês de junho de 1937 seria marcado por mais algumas manifestações de apoio à candidatura Salles e o início das campanhas dos candidatos à sucessão presidencial.

Quanto a Salles, uma nova alteraçđo significativa nas suas forças é a posse, no dia 3 deste mês, de José Carlos de Macedo Soares no Ministério da Justiça, a convite de Vargas. ${ }^{86}$ Soares, de imediato, declara assegurada a neutralidade de Getúlio, tenta desenvolver uma estratégia de normalização da política não renovando o Estado de Guerra e libertando mais de 400 presos políticos, porém, diz-se favorável a José Américo.

Por outro lado, em 9 de junho, seria divulgado em Sao Paulo um manifesto dos dissidentes do PRP, chefiados por Silvio de Campos, apoiando A. Salles. ${ }^{87}$

A situação, todavia, é bastante complexa. Paralelamente a tudo isto Plínio Salgado reascende à cena política dizendo-se candidato à sucessão de Vargas escolhido por cerca de 850.000 membros da Ação Integralista Brasileira. ${ }^{88}$

Sob as intempéries antes mencionadas, além de outras, a batalha eleitoral prossegue, tendo seu desfecho normal nas urnas mais uma vez sido assegurado por Vargas quando este especulara sobre seu sucessor na mensagem que enviou à reabertura dos trabalhos do Congresso. ${ }^{89}$

E Salles, em alguma medida, confia nessa possibilidade. Tanto que passa vários dias no Rio de Janeiro no começo de junho articulando todos seus 
apoios até decidir-se pela formação de uma agremiação partidária de cunho nacional que sirva de suporte para a sua candidatura e para a realização de sua plataforma. Isso seria concretizado na fundação da Uniao Democrática Brasileira. ${ }^{90}$

Assim é que, depois de algumas deliberações, os parlamentares que o apoiavam como João C. Machado, Otávio Mangabeira, Arthur Bernardes, J.J. Seabra, Eurico de Souza Leđo, entre vários outros, fundam o novo partido no Palácio Tiradentes. Mais tarde, ao ser oficialmente comunicado a criação da nova agremiação partidária nacional em seu apoio, Armando de Salles proclama mais uma vez a democracia como cerne da nacionalidade brasileira - vale dizer a periódica livre apuração da vontade da maioria através de eleiçóes e compromete-se a defender tal orientação na UDB: "A Uniao Democrática Brasileira visa congregar todos os brasileiros debaixo da idéia nacional, na defesa dos princípios democráticos que constituem a realidade substancial do país." 91

$\mathrm{E}$, além disso, repudia qualquer espírito regionalista na política brasileira, o que nao se confunde com sua defesa da "federação": "A idéia nacional deve ser entendida no sentido mais largo e mais alto. Condenável seria a predileção por uma parcela qualquer do país ou do povo para a outorga de favores que, a vingarem, corresponderiam a um desigual tratamento das regiōes e dos indivíduos dentro da mesma prática e implicariam um golpe contra a Federaçao. ${ }^{92}$

Salles desenvolve pois uma particular combinação de defesa da Federação e combate ao regionalismo, naquele momento tanto mais valioso na medida em que a candidatura concorrente de José Américo ganhava cada vez mais a caracterizaçao de "representante do Norte" do país. Enfim, a concepção de "regionalismo", para Salles, significava um indevido e privilegiado atendimento de interesses regionais, enquanto que a idéia de "Federação" representava uma equilibrada convivência da diversidade regional, sem abandonar a idéia de um Executivo forte e centralizado.

Alguns daqueles e outros pontos de sua plataforma seriam reafirmados no comício de lançamento público da União Democrática Brasileira em 16 de julho de 1937.

A data escolhida, por si, já significa alguma coisa, pois é o aniversário da reconstitucionalização do Brasil, comemoração da qual não se faz qualquer segredo.

Nesta manifestação pública realizada no estádio do América Futebol Clube, Salles defenderá com ênfase e, pela primeira vez, a importância dos partidos nacionais para o sucesso da organizaçao republicana brasileira. $\hat{\mathrm{E}}$ este tipo de agremiação que a UDB visa ser: "Apresentando-nos como uma uniao de partidos, primeira etapa forçada para atingirmos ao partido nacio- 
No Paraná, a instalação da UDB contou com a presença de Sampaio Correia e Otávio Mangabeira, sendo que este teve uma cerimônia em sua homenagem realizada no Palácio Teatro de Curitiba. ${ }^{105}$

Um outro apoio de peso à UDB e à candidatura Salles veio do Ceará, estado no qual esta corrente obteria o apoio de 77 dos 81 diretórios municipais do Partido Social Democrático. ${ }^{106}$

Deve-se registrar, por último, manifestaçбes de apoio com intensidade variável, porém não desimportantes, oriundas dos estados de Mato Grosso, Amazonas, Pará, Maranhao, Sergipe, Espírito Santo, Estado do Rio, Distrito Federal e Santa Catarina. ${ }^{107}$ Estes constituíram-se de manifestaçбes individuais, formação de dissidências, ou mesmo novos partidos atuando no sentido de promover a candidatura Salles, desde o seu período de lançamento oficial em 15 de maio até às vésperas do golpe.

Por outro lado, José Américo enfrentaria mais que apenas dificuldades legais na sua candidatura. Sua campanha ño ganha a esperada ressonância e ele chega mesmo a desagradar às elites que o apoiavam ao fazer pronunciamentos que o distinguiam do situacionismo federal e que acenavam com mudanças em favor das camadas inferiores da sociedade. ${ }^{108}$

Desde o final de junho, Armando de Salles contaria igualmente com pronunciamentos diários em favor da sua candidatura, através da Rádio Tupi do Rio de Janeiro. Por seus microfones passaram todos os grandes líderes da UDB e até militares simpáticos a causa desta agremiação como Euclydes Figueiredo. ${ }^{109}$

Por outro lado, o jornal "O Estado de São Paulo" acolheria desde 5 de agosto em uma de suas páginas o "Jornal do PC", uma página diária totalmente voltada para a propaganda da candidatura Salles, publicação que circularia até às vésperas do golpe. ${ }^{110}$

Depois de sua campanha por Minas, Salles visitaria seu outro grande aliado que era o Rio Grande do Sul, onde viria a cumprir uma extensa programaçao.

Armando de Salles chega à capital gaúcha dia 11 de setembro, cidade na qual faria dois pronunciamentos públicos à semelhança de como fizeram em Belo Horizonte: um em campo aberto e outro em recinto fechado.

No seu primeiro discurso, no Parque Farroupilha, com um público calculado pelo jornal que o apoiava em 60.000 pessoas, Salles relembraria e exaltaria extensamente a histórica e ativa tradição política do Rio Grande do Sul, especificidade deste estado no cenário nacional, um passado que teria igualmente lá criado um "verdadeiro" espírito democrático como era entendido por aquele candidato: "Ao mesmo tempo criou o interesse pela causa pública e pela vida política do país, cultivando no povo o sentimento partidário, que é o verdadeiro espírito político nas democracias." 
Salles reafirma sua especificidade na disputa eleitoral que então se travava, em particular, seu alinhamento a um tipo de atividade política "mais elevada" e que deixa raízes no Rio Grande do Sul: "As boas sementes da seara lavrada por Júlio de Castilhos e Gaspar Martins precisam ser renovadas. No Brasil, a escola cívica em que ño se discutem pessoas e ambições e só se debatem idéias e princípios perde pouco a pouco os seus freqüentadores. ${ }^{112}$

Além disso, sustenta mais uma vez os princípios substantivos dos quais é portadora sua candidatura, proposta que também têm estreitas afinidades com o estado do extremo sul brasileiro: "O sentimento de autonomia dos estados, o zelo pela sua dignidade e o propósito de assegurar a pacífica transmissao da presidência, preservando, com o estrito cumprimento da constituição, a unidade nacional, atrairam todos que se sustentam com a mesma fé e o mesmo ânimo."113

No interior gaúcho, Salles visitaria as cidades de Santa Maria, Montenegro, Caxias, Novo Hamburgo, Pelotas e depois voltaria para a capital federal. ${ }^{114}$ Nessas longas andanças e articulações, destaca-se sua referência a questão da defesa nacional e à precária situação das forças armadas para dar conta de seu natural encargo. Por duas vezes, refere-se, com relativa atenção, à necessidade de uma ampla reorganizaçao das corporações militares, no sentido de sua modernizaçao e profissionalizaçao, consideraçðes que, entretanto, não ecoam junto a seus prováveis destinatários.

No início de outubro, a orientaçao golpista começa a se explicitar sob pressão das elites militares e de Vargas. O então Ministro da Justiça, José Carlos de Macedo Soares, solicita ao Congresso a aprovação do estado de guerra, tendo em vista a conturbada situação do país. Depois de acalorados debates e rápidos procedimentos tal medida é aprovada na Câmara dos Deputados com 128 favoráveis contra 52 votos contrários, oriundos das bancadas gaúcha e paulista. ${ }^{115}$

Este seria o primeiro passo no enfrentamento aberto entre as forças favoráveis a uma intervençđo na vida política brasileira e os opositores a tal alternativa.

O segundo movimento não tardaria e, com ele, estaria selada a sorte de todos os setores que não se alinhavam à intervenção autoritária que a esta altura claramente se delineava no poder central em estreita aliança com as altas patentes militares. Trata-se da nomeaçao dos governadores como executores do estado de guerra em todo o país, função da qual são excepcional e significativamente excluídos os chefes dos estados de Sao Paulo e Rio Grande do Sul. ${ }^{116}$

As oposiçбes a essa medida não tardam, porém já são impotentes para deter o processo e até denunciam a perspectiva de Vargas. Arthur Bernardes, 
por exemplo, discursa na Câmara Federal alguns dias depois afirmando que o estado de guerra foi uma medida instituída para permitir o continuismo de Vargas. Como igualmente já salientara Antonio Carlos, Bernardes lembra ainda que tal situação impedirá o livre prosseguimento das campanhas eleitórais. ${ }^{117} \mathrm{O}$ desenrolar dos acontecimentos confirmaria plenamente o pessimismo destes políticos.

A despeito de estar com sua viagem em campanha eleitoral pelo norte do país programada para a primeira quinzena de outubro, Salles permaneceu entre o Rio e São Paulo parecendo aguardar uma definiçđo ainda mais clara da conjuntura. Face à confirmação dos arranjos golpistas, ele lança o que pode ser bem definido como seu canto de cisne: através de Joao Carlos Machado e Paulo Morais de Barros faz com que seja lido na Câmara e no Senado respectivamente, seu famoso apelo às forças armadas para que garantam a vigência das instituiçб̃es democráticas no Brasil. ${ }^{118}$

A reação que ele obteve foi exatamente o inverso do que propunha. $\mathrm{Na}$ manhã do dia 10 de novembro as duas casas legislativas na capital federal amanheceram cercadas e impedidas de funcionarem por tropas militares. Antes do meio-dia era promulgada a nova constituiçao do país e Vargas fez um pronunciamento radiofônico sobre a nova situação do Brasil. ${ }^{119}$

A articulação e a ação militar que se desenvolveu no golpe não deve, todavia, ser vista como um fato extemporâneo, ño ligado à conjuntura de entao, apesar de pouco mencionada neste estudo. Nesta hora seu papel é decisivo. E, de fato, desenvolvia-se toda uma atuação das altas chefias militares, em particular Dutra e Góes, no sentido de manterem coesas suas corporaçбes, basicamente o Exército, no caso, frente às disputas políticas que então se travavam. Já no final de julho, o Dutra expediria recomendação nesse sentido ao pessoal militar, uma orientaçao que se repetiria em palavras e açбes. ${ }^{120}$

Paradoxalmente e coincidentemente, Sao Paulo, com sua Força Pública, e o Rio Grande do Sul, com seus corpos de "provisórios" apareceriam como os estados onde o Exército encontrava-se mais vulnerável ao controle local. No início de agosto desenvolve-se uma acirrada disputa entre Dutra e Flores sobre a existência de armamento do exército sob controle do governo do estado. ${ }^{121}$

O Ministro da Guerra, contudo, ia um pouco mais longe naquelas suas recomendaçóes. Ele lembrava ainda, que as forças armadas deveriam estar atentas para que a população nao fosse desvirtuada quanto à campanha eleitoral em andamento, por influências prejudiciais a esta. ${ }^{122}$

Tal tipo de desvirtuamento, nao da campanha eleitoral, mas da política brasileira como um todo, que veio a justificar a ação do Exército no Golpe foi provida pelo famoso e discutido Plano Cohen, um falso plano comu- 
nista para tomada do poder, preparado pelo Integralismo e apropriado pelo Exército. ${ }^{123}$

A Ação Integralista Brasileira, na verdade, há muito, procura a ascender politicamente com as perspectivas de uma intervençao golpista. Nesse sentido, os membros dessa organização promovem várias manifestaçōes pacíficas e outras com violência. Se de um lado, a AIB parece crescer e ganhar apoio no Governo, - colaborando inclusive no Golpe - de outra parte esta mesma agitação integralista seria logo vista e combatida como prejudicial à ordem política do país.

Algumas forças regionais foram igualmente articuladas antes do Golpe através de Negrão de Lima. Este foi o episódio denominado "Missão Negrao de Lima", na qual o deputado mineiro orientado e credenciado por Benedito Valadares, visitou vários estados do país, avaliando com os governadores locais as perspectivas de prorrogação dos mandatos e o adiantamento das elciçбes com uma reforma constitucional. Negrão de Lima não esteve na Bahia, no Sul e em Pernambuco, mas chegou a avistar-se com Cardoso de Mello, o qual se alinhou com a saída golpista. ${ }^{124}$ A missđo foi bem sucedida na perspectiva do situacionismo federal.

\section{SÃO PAULO E O ESTADO NACIONAL - CONSIDERAÇÕES FINAIS}

Como bem se sabe, diante do apelo de Salles às forças armadas para garantirem a democracia brasileira e a realização das eleiçбes, os militares responderam com o "gesto que mata" e nao "a palavra que salva", nos termos nos quais ele colocou a questao em 9 de novembro.

Mais uma vez, Sđo Paulo lidera, com um projeto liberal, pluralista, uma proposta perdedora em termos ao controle direto do poder central do país. E mais uma vez, forças oligárquicas periféricas, aliadas a setores das oligarquias de Minas, Såo Paulo e Rio Grande do Sul conseguiram manter-se em posiçðes dominantes contando, nesse caso, com a preciosa ajuda das elites militares que viam sua corporaçao como ameaçada pela agudizaçao do conflito político no país.

Ao Golpe de Estado de 10 de novembro de 1937 segue-se um período de extremo autoritarismo o chamado "Estado Novo" sobre o qual só agora começa-se a ter maiores informações.

Enfim, observando essa conjuntura de 1936/1937 de uma perspectiva mais ampla, isto é, considerando o periodo estadonovista que se segue e, previamente, a República Velha até 1935 aproximadamente, pode-se, talvez, situar nesses anos um momento crucial de redefiniçao da política oligárquica, que, de 1945 em diante, conviverá com períodos de ampla ou 
reduzida participaçđo política.

Nestes termos, sem desconsiderar fatores estruturais como a urbanização e industrialização do país, o desfecho autoritário de 1937 envolveu um veto radical às propostas de continuação e mudança da política oligárquica sob regras de aberta competição politica como decisivamente propunha o candidato paulista, apoiado em significativas forças regionais. Por outro lado, a própria existência de outros dois candidatos à sucessão presidencial sustentavam esta alternativa, ainda que, com suas particularidades, pareciam caminhar para extremos opostos.

Dessa forma, este desfecho autoritário deve ser considerado também frente ds alternativas existentes dentro das elites políticas e nao apenas em relaçao aos grupos opostos a elas, e a cuja intensa mobilização se tem atribuído, imprecisamente, a nosso ver, o Golpe de 37. A emergência das camadas médias urbanas e do operariado já poderia tê-las introduzido nos cálculos políticos dos setores dominantes, porém, é igualmente observável que tais setores já nđo se apresentavam como significativas forças sociais ativamente contestadoras do status quo em 1937. Nesta conjuntura, tratava-se de controlar fundamentalmente as condições sob as quais se redefiniria as disputas intra-elites. Dentre essas apareceriam como particularmente problemáticas as demandas capitaneadas por Salles propugnando pela via democrático-liberal para a vida política brasileira. As alternativas representadas pelas outras candidaturas de José Américo e de Plínio Salgado nao pareciam igualmente adequadas, tendo em comum com a primeira a perspectiva de um alto grau de participação política. Contra isso se dá o Golpe de 37 e contra isso se busca construir uma nova ordem com o Estado Novo.

\section{NOTAS}

1 - Também ao contrário da reflexão sobre a Revolução de 30, não se conhecia, até muito recentemente, uma maior prcocupação analítica com o Golpe de 37 e o Estado Novo, situaçao que parece estar se modificando.

2 - A lacuna, na verdade, já é menor, pois hoje se conta com um trabalho, do qual nos estaremos valendo, que, trata especificamente deste tema. Ver: Plínio de Abreu Ramos. Os partidos paulistas e o Estado Novo. Petrópolis, Vozes, 1980. Pela reconhecida particularidade de São Paulo na política brasileira, estamos nos referindo às formula- 
çбеs de Simon Schwartzman sobre este estado: Simon Schwartzaman. Buses do autoritarismo no Brasil. Rio de Janeiro, Campus, 1982. Ver também, no mesmo sentido: Thomas W. Palmer Jr. São Paulo in the Brazilian Federation: State out of Balance. Ann Arbor. Univ. Microfilms, 1950. 199p. Tese (Ph.D.). University of Columbia, 1950. Por último, cabe ainda assinalar o recente livro de Joseph Love: São Paulo in the Brazilian Federation, 1889-1937. Stanford, Stanford University Press, 1980. Salles, na verdade, foi objeto de um livro, porém de caráter puramente laudatório: A.C. Pacheco e Silva. Armando de Salles Oliveira. São Paulo, Martins. 1966, onde pode-se encontrar algumas indicaçðes bibliográficas, mas com o mesmo teor do livro.

3 - GV 37.11.08/4. Citaçðes desse tipo indicam referências de documentos do CPDOC. As duas primeiras letras identificam o arquivo - no caso Arquivo Getúlio Vargas - e os números seguintes identificam o documento.

4 - Ângela M. de C. Gomes. "O redescobrimento do Brasil” in: Lucia Lippi Oliveira et alli, Estado Novo: Ideologia e Poder, Rio de Janeiro, Zahar, 1982.

5 - Thomas E. Skidmore. Brasil: de Getúlio Vargas a Castelo Branco (1930-1964). 4a ed. Rio de Janeiro, Paz e Terra, 1975, p.52.

6 - Robert M. Levine. O Regime de Vargas: os Anos Criticos, 1934 1938. Rio de Janeiro, Nova Fronteira, 1980. Esta é também a ótica do trabalho de Hélio Silva e Edgard Carone. Ver: Hélio Silva, 1937. Todos os Golpes se Parecem. Rio de Janeiro. Civilização Brasileira, 1970. Edgard Carone. A República Nova (1930-1937). Sao Paulo, Difel, 1976.

7 - Lourdes Sola. "O Golpe de 37 e o Estado Novo", in Carlos Guilherme Mota (org.) Brasil em Perspectiva. 9a ed. Sao Paulo, Difel, 1977.

8 - Idem, p.264.

9 - Ibidem, p.270.

10 - Werner Baer e Annibal V. Villela "Industrial Growth and Industrialization: Revision in the Stages of Brazil's Economic Development". Journal of Developing Areas, 7 (jan. 1973), p.222.

11 - A negação da possibilidade de uma organização democrático-liberal para o Brasil tem longa tradição da nóssa vida e pensamento políticos. Uma das principais e esclarecedoras recuperaçбes desta ideologia é: Bolívar Lamounier "Formação de um Pensamento Político Autoritário na Primeira República. Uma interpretaçao" in. Bóris |Fausto (org.), História Geral da Civilizaçáo Brasileira; o Período Republicano. São Paulo, Difel, 1981. t.3. v.2. 
12 - GV 37.11.08/1 v.28/10.

13 - Plínio de Abreu Ramos. Os Partidos Paulistas e o Estado Novo. Petrópolis, Vozes, 1980.

14 - Idem, p.208.

15 - Correio da Manhã, 16/05/3/, daqui para a frente citado como CM.

16 - CM 30/12/36. O Estado de Sáo Paulo, 30/12/36, daqui para a frente citado como ESP.

17 - ESP 30/12/36.

18 - Sobre as negociaçбes em torno do nome de Salles ver: Hélio Silva, op.cit., pp.293-294.

19 - ESP 30/12/36. CM 08/04/37.

20 - Vicente Rao. Vicente Rao (Depoimento 1976). Rio de Janeiro, FGV/CPDOC - História Oral.

21 - Alzira Vargas do Amaral Peixoto. Getúlio Vargas, meu pai. Porto Alegre, Globo, 1960.

22 - Diário da Manhã, 01/09/37.

23 - ESP 02/01/37.

24 - Rodrigo B.M. Coelho, Lucia L. Lobo e Angela M.C. Gomes, "Revolução e restauração: a experiência paulista no período da constitucionalização", in Ângelo M.C. Gomes (coord.), Regionalismo e Centralizaçẫo Politica, Partidos e Constituintes nos Anos 30. Rio de Janeiro, Nova Fronteira, 1980. p.294.

25 - Plínio de A. Ramos, op.cit., p.169.

26 - Rodrigo B.M. Coelho et alli, op.cit., p.276.

27 - Idem., p.275.

28 - Ibidem.

29 - Plínio de A. Ramos, op.cit., p.171.

30 - CM 18/04/36. ESP 26/04/36.

31 - CM 18/04/36. ESP 26/04/36.

32 - Rodrigo B.M. Coelho et alli, op.cit., p. 332.

33 - Plínio de Abreu Ramos, op.cit., p.174.

34 - ESP 16/02/36.

35 - Plínio de A. Ramos, op.cit., pp.174-184.

36 - ESP 01/01/36. CM 01/01/36.

37 - Hélio Silva, op.cit., p.8 e pp.125.134. Em sua correspondência particular, Getúlio demonstra o mesmo nível de preocupação com o comunismo. Cf AGV, v. 21 , doc.12, de 11/01/36.

38 - ESP 25/01/36. CM 26/01/36.

39 ... СM 29/01/36. ESP 28/01/36.

40 - Esta situação encontra-se muito bem recuperada em: Robert. M. Levine, op.cit. e Hélio Silva, op.cit. 
41 - ESP 10/01/36, 11/01/36. CM 10/01/36.

42 - ESP $14 / 02 / 36$.

43 - ESP 14/02/36.

44 - ESP $14 / 02 / 36$.

45 - Armando de Salles Oliveira Jornada democrática; discursos políticos. Rio de Janeiro, José Olympio, 1937, p.26.

46 - Idem., p.7.

47 - Ibidem., p.27.

48 - Ibidem., p.14.

49 - Ibidem., p.4.

50 - Ibidem., p.5.

51 - Ibidem., p.20.

52 - Ibidem., p.17.

53 - Ibidem., p.18.

54 - Ibidem., p.31.

55 - Vicente Rao, ao receber jornalistas cariocas no Palácio de Campos Alíseos, assinalou que a democracia é a forma mais estável de governo e que o nosso sistema presidencialista está ganhando força devido à crescente necessidade de defender o Estado contra os extremismos. CM 28/01/36.

56 - Assis Chateaubriand, na verdade, desenvolveria uma intensa campanha em 1937 contra o alinhamento ao situacionismo federal do PRP, ao mesmo tempo que defenderia o PC e Armando de Salles, vendo nele a continuação dos ideais da Revolução de 30 . Por outro lado, Paim Filho diria que a renúncia nđo teve qualquer ressonância nos meios políticos. CM 03/01/37, 08/01/37. ESP 03/01/37, 08/01/37.

57 - GV 36.12.23/1. Vargas responde formalmente à comunicaçao que Salles lhe faz de sua renúncia: Cf. ESP 01/01/37.

58 - ESP 08/04/37.

59 - CM 20/02/37.

60 - ESP 13/01/37.

61 - ESP 23/01/37.

62 - ESP 26/01/37.

63 - ESP 26/01/37.

64 - ESP 26/01/37.

65 - ESP 26/01/37.

66 - ESP 26/01/37.

67 - ESP 26/01/37.

68 - ESP 19/01/37, 22/01/37, 27/01/37 e 28/01/37.

69 - Hélio Silva, op.cit., p.313.

70 - ESP 02/04/37. 
71 - ESP 25/04/37.

72 - ESP 25/04/37.

73 - ESP 25/04/37.

74 - ESP 16/05/37. Além disso, Armando de Salles, na verdade, tornarase o presidente do Partido Constitucionalista em 13 de fevereiro. Ver ESP 14/02/37.

75 - ESP 16/05/37.

76 - ESP 16/05/37.

77 - ESP 1-6/05/37.

78 - ESP 11.04.37, ocasião na qual Salles discursaria, reafirmando mais uma vez os princípios de sua plataforma.

79 - ESP 25/05/37.

80 - ESP 30/04/37, 01/05/37.

81 - ESP 05/05/37. CM 05/05/37.

82 - ESP 29/04/37.

83 - ESP 07/04/37. A partir desta intervençăo, será observada toda uma movimentaçao das elites militares, em particular Góes Monteiro e Dutra, no sentido de manterem coesas as forças armadas, cuja unidade era vista como ameaçada pela agudização do conflito político entre as elites regionais.

84 - ESP 09/03/37, 17/03/37, CM 17/03/37.

85 - CM 26/05/37, 20/05/37.

86 - ESP 29/05/37, 04/06/37, 15/06/37.

87 - ESP 10/06/37. Este grupo seria excluído do PRP na convenção do partido que decidiu pelo apoio a José Américo. CM 08/07/37.

88 - ESP 10/06/37. CM 12/06/37.

89 - ESP 04/05/37. Semelhante confiança na realizaçăo das eleiçres pode ser também deduzida de seu ambíguo discurso de 7 de setembro: ESP 08/09/37.

90 - ESP 11/06/37.

91 - ESP 11/06/37.

92 - ESP $11 / 06 / 37$.

93 - ESP 17/07/37. Depois de fundado, o partido seria instalado no dia 2 de julho com a presença de praticamente todos os principais integrantes da direção da UDB. ESP 03/07/37.

94 - ESP 17/07/37.

95 - ESP $17 / 07 / 37$.

96 - ESP 17/07/37. CM 17/07/37.

97 - ESP 15/08/37.

98 - ESP $15 / 08 / 37$

99 - ESP 17/08/37 
100 - ESP 17/08/37.

101 - ESP 17/08/37.

102 - Plínio de A. Ramos. op.cit., pp.191-200.

103 - ESP 08/09/37, 09/09/37, 10/09/37.

104 - ESP 25/05/37, 15/06/37. CM 25/05/37.

105 - ESP 29/07/37.

106 - ESP 16/06/37. Nessa disputa, a Uniao Democrática Brasileira receberia a concessão de seu registro na Justiça Eleitoral, tendo Armando de Salles como seu candidato a sucessđo presidencial, situaçao que José Américo nao alcança tendo em vista o fato de que não abandona seu cargo público. ESP 24/08/37.

107 - ESP 08/05/37, 12/05/37, 20/05/37, 25/05/37, 27/05/37, 30/05/37, $15 / 06 / 37,17 / 03 / 37,22 / 06 / 37$. CM 20/05/37, 30/05/37, 15/06/37.

108 - O Globo, 17/09/37.

109 - ESP $13 / 07 / 37$.

110 - ESP 05/08/37.

111 - ESP 12/09/37. Esta viagem ao Rio Grande do Sul, raramente sequer mencionada nas referências a esse período, assume maior importância na medida em que Flores da Cunha estava de novo com maioria na assembléia legislativa gaúcha: ESP 29/08/37.

112 - ESP 29/-8/37.

113 - ESP 29/08/37.

114 - ESP 14/09/37, 15/09/37, 16/09/37, 17/09/37.

115 - ESP 02/10/37.

116 - ESP 08/10/37. EM 08/10/37.

117 - ESP 09/10/37, 10/10/37. CM 09/10/37, 10/10/37.

118 - Hélio Silva, op.cit., pp.455-469. Neste livro pode-se encontrar a transcriçao do manifesto.

119 - Idem.

120 - ESP 01/08/37.

121 - СM 03/08/37, 07/08/37.

122 - ESP 01/08/37.

123 - Hélio Silva, op.cit., pp.375-383.

124 - ESP 04/11/37, 05/11/37.

*Este trabalho é um produto parcial e pessoal de uma pesquisa sobre a conjuntura 1935-1937 desenvolvida junto a outros pesquisadores no CPDOC (Centro de Pesquisa e Documentação de História Contemporânea do Brasil) da Fundação Getúlio Vargas; pelas valiosas contribuiçōes recebidas em vários momentos da pesquisa, sou muito grato aos membros desse grupo de trabalho: Aspasia Camargo, Dulce Pandolfi, Mário Grynzpan e Maria Celina S. de Araújo. 
A Campanha Presidencial de Armando de..

* *Professor de Ciência Política da UFF e da PUC-RJ, atualmente em estudos doutoramento na Universidade de Chicago.

Departamento de Ciência Política.

Universidade Federal Fluminense

Caixa Postal

24.210 Niterói - RJ. Brasil 